\title{
Examining the Influence of Media Ownership Concentration on Radio Programing Diversity in Kenya
}

\author{
Allan S. Wekesa ${ }^{1 *}$, Proffesor. Hellen M Kinoti ${ }^{2}$, Dr. Lilian Omoke ${ }^{3}$ \\ ${ }^{I}$ Department of Communication Studies, Technical University of Mombasa \\ ${ }^{2}$ Dean, School of Communication and Development Studies, JKUAT, Kenya \\ ${ }^{3}$ Lecturer, Department of Humanities, Embu University, Kenya
}

*Corresponding Author: Allan S. Wekesa, Department of Communication Studies, Technical University of Mombasa

\begin{abstract}
While radio is Kenya's most dominant and effective medium of mass communication. The question of ownership concentration present numerous challenges to programming diversity. The programming format is characterized more by sameness, radio stations find it more profitable to duplicate mass appeal programming formats. Such rational business decisions come at the expense of the listening audience which is given few formats from which to choose. The study was anchored on the theory of media ownership and the political economy of the media theory. The study adopted a mixed research design method combining both qualitative and quantitative data. The study found out that the media owners influence programming decisions thus affecting diversity. The study confirmed previous research which showed a negative relationship between ownership concentration and radio programming diversity. Likewise the findings related an increase in format diversity with an increase in the number of competitors.
\end{abstract}

\section{INTRODUCTION}

Baker, (2007) opines that freedom of the press belongs to those who own one. This rather suspecious observation makes the study of ownership paramount in media research. At the top of the organization structure are the owners. Ultimately media owners or their appointed top executives have the final say on the programming decisions. (Doyle, 2006).

According to Edwin Baker, the greatest threat to freedom of expression is the possibility that private entrepreneurs will always tend to monopolies the marketplace of ideas in the name of economic efficiency and private profit (Baker 2007). The mass media industry is crucial for the creation of reliable information, knowledge, ideology and propaganda in contemporary capitalist societies. As Strinati, (1995) argues, its structure of ownership and control are equally crucial. Marxist critical studies claim that the mass media assume an all encompassing conspiracy by monopolist (Gomery 2006). Political economists like Golding and Murdock (2001) see the relationship between ownership and control as an indirect and mediated one.

Nyabuga (2009) asserts that a strong, fair, objective and independent electronic media helps in development of vibrant democracies and progressive societies. McQuail, (2005) emphasises that the media are crucial to the development of stable and functioning democracies and mature societies. $\mathrm{He}$ contends that one of the factors that determine the efficiency of the media in fulfilling their sociopolitical role is how they are owned and controlled. He states that for a media to effectively succeed in its role of informing the society there must be editorial independence. Radio plays an important role through its programming that is informing, educating and entertaining. Given this vital role, the ownership of radio stations and the availability of diverse and independent programming has been an issue of concern to media scholars. One such concern, in particular is that with increasing radio ownership consolidation, the number of distinct media voices and selection choices for the listener has diminished. Research has shown that media owners may directly or indirectly interfere with editorial content and agenda (Napoli, 2006). They may do so directly through the appointment of media personnel to senior positions that directly share their ideological orientation and readiness to pursue their content prescription in favor of the owner or indirectly through financial investments in programmes they consider favorable (Napoli, 2006). This according to Napoli, is complicated by 
commercial media that is supported by advertising and sponsorship where content are often viewed in terms of commercial and economic gains (Napoli, 2006). This narrows content diversity and affects open cultural representation of all segments in the society (Golding and Murdock 2001; McChesney 2008). It is, therefore, important to understand the interplay between commercial imperatives, media ownership patterns and legal framework and how they influence diversity of programming.

\section{THEORETICAL REVIEW}

This study is anchored on the theory of media ownership and the political economy of the media

\subsection{Theory of Media Ownership}

The theory of media ownership developed by Altschull contends that "the content of the press is directly correlated with the interests of those who finance the press" (Altschull, 1984). The autonomy of media outlets is given within the boundaries of owners' profit. Where the media outlet is commercially owned the content will reflect the point of view of the news organization's owners and advertisers. Where the media outlet fits into where the media outlet fits into what Altschull calls an "interest pattern," the content mirrors the concerns and objective of whoever is providing the financing. Shoemaker and Reese (1991) have attempted to refine and extend Altschull's work (Altschull, 1984). Their theory of media ownership and news content points out that the owners of a media organization have the ultimate power over the news content. They contend that primary focus of a news organization owned by a publicly held corporation is to make profit, and objectivity is seen as a way of attracting the readers desired by advertisers. Thought in some rare cases, the owner may choose to make profits secondary to an ideological goal, such as promoting a particular agenda, the organization can't indefinitely ignore the economic goal. Especially when media firms are owned by stockholders, public service is usually sacrificed for the sake of profitability.

\subsection{Political Economy of the Media Theory}

The manner in which the media operates is shaped by their owners, the market environment and the financial support. In this environment, the media manufactures cultural content that sustains the system 'capitalism' (Chomsky, 2008). The media is in the business of maximize profits just like any other business organization in capitalism (Williams, 2003; Mc Chesney, 2003; Mosco, 1996; Hesmondhalgh, 2007). The theory argues that the product or the content of the media may be shaped by corporate interests, basically, interest of the owners. Media owners ensure they appoint journalists who share the same ideologies as theirs in the market driven system into managerial position to sustain their interests and the interests of a particular class (Nyabuga, 2009). News and investigative reports that journalists produce have a value attached to it for maximizing profits (Chambers, 2006). The media is thus obliged to meet the needs of owners, the audiences; advertisers as well as media employees by employing a delicate balance between these stakeholders (Picard, 1989). This obligations influence media content (Gandy, 1997).

\section{CONCEPTUAL FraMeWORK}

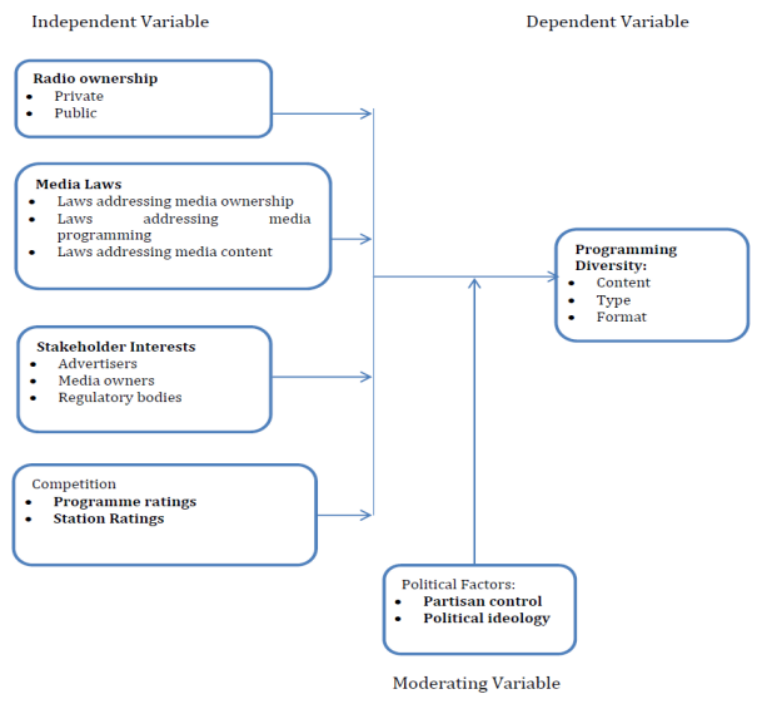

Figure1. Conceptual Framework 


\section{Methodology}

The study was conducted in Nairobi at the headquarters of the Royal Media Group, Media Max and the Kenya Broadcasting Corporation. Since the objectives of the study were primarily to establish the influence of media owners on programming diversity, it was important to conduct the study at the station's headquarters. The location accommodates the majority of the staff amongst who were the primary informants namely the programming managers. The secondary informants included reporters and radio presenters. The study population comprised of a diversity of respondents including reporters and programming managers from six radio stations. Two programme managers from Royal media services representing Citizen radio and Bahari FM. Two programme managers from Media max representing Radio Maisha and Pilipili FM and Two programme managers from the Kenya Broadcasting Corporation representing Pwani FM. The respondents were important in assessing the extent to which radio station ownership has influenced programming diversity.

\section{Data Collection AND ANALYSIS}

Quantitative data was collected using questionnaires while interviews of key informants was used to gather qualitative data. SPSS version 22, was used to analyze quantitative data. The statistics included frequencies, correlation, and regression. Qualitative data from key informants that included programme managers and radio presenters was used to compliment the quantitative statistics. Given the qualitative nature of this study, purposive sampling was used to select the study respondents. This type of sampling was applied because the study aimed at specific and in-depth information from officials directly involved in decisions and actions regarding programming. By conducting research with such respondents and schedules proportion the researcher expected to get deeper understanding of the subject of the study and a wider perspective into the research problem. A total of 230 questionnaires were administered to the six radio stations, 12 respondents were selected to be interviewed for this study.

\section{ReSUlts}

\subsection{Descriptive Results}

There were three variables whose composition was analyzed. These include the name of the radio station, subsidiary and ownership.

Radio station

\begin{tabular}{|l|l|l|}
\hline Name of Radio Station & Frequency & Percent \\
\hline Radio Maisha & 20 & 9.5 \\
\hline Pilipili FM & 32 & 15.2 \\
\hline Pwani FM & 36 & 17.1 \\
\hline KBC Idhaa ya Taifa & 44 & 21.0 \\
\hline Citizen Radio & 40 & 19.0 \\
\hline Bahari FM & 38 & 18.1 \\
\hline Total & 210 & 100 \\
\hline
\end{tabular}

Results from Table show that KBC Idhaa ya Taifa had the highest proportion of representation at $21 \%$, followed by Citizen Radio and Bahari FM at $19 \%$ and $18.1 \%$ respectively. Radio Maisha had the least representation at $9.5 \%$. This shows that there was fair representation of all the stations.

\subsection{Ownership}

The radio stations were either privately owned or public owned. $61.9 \%$ in the sample were privately owned while only $38.1 \%$ are publicly owned. The results are presented in the table below

Table4.3. Ownership

\begin{tabular}{|l|l|l|}
\hline Form of Ownership & Frequency & Percentage \\
\hline Public & 80 & 38.1 \\
\hline Private & 130 & 61.9 \\
\hline Total & 210 & 100.0 \\
\hline
\end{tabular}

\section{Reliabilty}

Reliability measures the consistency of the tools of data collection. Cronbach's alpha is usually used to test the reliability of the tools of data collection. Cronbach's alpha value of higher than 0.7 indicates that the tools are reliable. In this research Cronbach's alpha was used to test the reliability of 
the proposed constructs (Ali et al., 2016). The result shows that the overall reliability Cronbach's Alpha is 0.833. All the variables had Cronbach's Alpha of more than 0.7 as given in Table 4.5. This shows that the tools used to collect the data set were reliable and consistent. Therefore, the data is adequate for further analysis.

Table4.5. Reliability Statistics

\begin{tabular}{|l|l|}
\hline Cronbach's & N of Items \\
\hline 0.833 & 30 \\
\hline
\end{tabular}

Table4.5. Reliability Statistics for individual variables

\begin{tabular}{|l|l|}
\hline Variable & Cronbach's Alpha \\
\hline Ownership & 0.738 \\
\hline Laws & 0.878 \\
\hline Stakeholder's interest & 0.789 \\
\hline Competition & 0.750 \\
\hline Political Factors & 0.713 \\
\hline Programming Diversity & 0.816 \\
\hline
\end{tabular}

\subsection{Factor Analysis for Ownership}

To check on the sample adequacy of the data, KMO was used to check on the sample adequacy of the data. KMO value ranges between 0 and 1 with value more than 0.5 considered to be ideal, Ali et al (2016). For the Bartlett's test to be considered should have a p value of less than 0.05 for it to be considered significant, it must have a $\mathrm{p}$ value of less than 0.05.Table 4.6 shows that KMO was 0.540 and Bartlett's test of Sphericity had a p value of 0.000 which is less than 0.05 . Therefore the data can be subjected for further factor analysis tests.

Table4.6. KMO and Bartlett's Test

\begin{tabular}{|l|l|}
\hline Kaiser-Meyer-Olkin Measure of Sampling Adequacy. & .540 \\
Approx. Chi-Square & 45.562 \\
Bartlett's Test of Sphericity Df & 10 \\
Sig. & .000 \\
\hline
\end{tabular}

Factor analysis helps in regrouping data into exhaustive and mutually exclusive clusters for ease of understanding and interpretation of relationships and patterns, Yong \& Pearce (2013). Principal component analysis was used to reduce components of performance. All the constructs of ownership were subjected to factor analysis and results given in Table 4.7

Table4.7. Total Variance Explained

\begin{tabular}{|l|l|l|l|l|l|l|}
\hline \multirow{2}{*}{ Component } & \multicolumn{4}{|l|}{ Initial Eigenvalues } & \multicolumn{3}{l|}{ Rotation Sums of Squared Loadings } \\
\cline { 2 - 7 } & Total & \% of Variance & Cumulative \% & Total & \% of Variance & Cumulative \% \\
\hline 1 & 1.491 & 29.813 & 29.813 & 1.358 & 27.157 & 27.157 \\
\hline 2 & 1.140 & 22.806 & 52.619 & 1.273 & 25.462 & 52.619 \\
\hline 3 & .984 & 19.679 & 72.298 & & & \\
\hline 4 & .703 & 14.057 & 86.355 & & & \\
\hline 5 & .682 & 13.645 & 100.000 & & & \\
\hline
\end{tabular}

Table 4.7 shows that two factors had the greatest influence on the variations in growth. The two factors accounted for $52.619 \%$ of all the variations. The first factor accounted for $29.813 \%$ while the second one accounted for $22.806 \%$. The two factors had Eigen values of more than one and are therefore retained for further analysis.

Rotated Component Matrix

Table 4.8 presents the rotated component factor loadings for determinants of measures of growth. Two factors were retained. All the constructs with loading values of more than 0.4 were retained.

Table4.8. Rotated Component Matrix ${ }^{a}$

\begin{tabular}{|l|l|l|}
\hline \multirow{2}{*}{} & \multicolumn{2}{|l|}{ Component } \\
\cline { 2 - 3 } & 1 & 2 \\
\hline Private radio ownership concentration influences radio station programming content & .456 & \\
\hline $\begin{array}{l}\text { Government radio ownership concentration doesn't influence radio stations programming } \\
\text { content }\end{array}$ & & .775 \\
\hline Private radio ownership concentration ensures programming originality & & .751 \\
\hline
\end{tabular}




\begin{tabular}{|l|l|}
\hline Government radio ownership concentration influences programming format & .774 \\
\hline Private radio ownership concentration influences programming type & .711 \\
\hline Extraction Method: Principal Component Analysis & \\
Rotation Method: Varimax with Kaiser Normalization & \\
a. Rotation converged in 3 iterations & \\
\hline
\end{tabular}

\subsubsection{Factor Analysis for Laws}

To check on the sample adequacy of the data, $\mathrm{KMO}$ was used to check on the sample adequacy of the data. KMO value ranges between 0 and 1 with more than 0.5 considered to be ideal, Ali et al (2006). For the Bartlett's test to be considered should have a $\mathrm{p}$ value of less than 0.05 for it to be considered significant, it must have a $\mathrm{p}$ value of less than 0.05.Table 4.6 shows that KMO was 0.540 and Bartlett's test of Sphericity had a p value of 0.000 which is less than 0.05 . Therefore the data can be subjected for further factor analysis tests.

Table4.8. KMO and Bartlett's Test

\begin{tabular}{|l|l|}
\hline Kaiser-Meyer-Olkin Measure of Sampling Adequacy. & 0.789 \\
Approx. Chi-Square & 718.229 \\
Bartlett's Test of Sphericity Df & 10 \\
Sig & .000 \\
\hline
\end{tabular}

Factor analysis helps in regrouping data into exhaustive and mutually exclusive clusters for ease of understanding and interpretation of relationships and patterns, Yong \& Pearce (2013). Principal component analysis was used to reduce components of law. All the constructs of ownership were subjected to factor analysis and results given in Table 4.9

Table4.9. Total Variance Explained

\begin{tabular}{|c|c|c|c|c|c|c|}
\hline \multirow{2}{*}{ Component } & \multicolumn{3}{|c|}{ Initial Eigenvalues } & \multicolumn{3}{c|}{ Extraction Sums of Squared Loadings } \\
\cline { 2 - 7 } & Total & \% of Variance & Cumulative \% & Total & \% of Variance & Cumulative \% \\
\hline 1 & 3.469 & 69.383 & 69.383 & 3.469 & 69.383 & 69.383 \\
\hline 2 & .846 & 16.922 & 86.305 & & & \\
\hline 3 & .276 & 5.513 & 91.818 & & & \\
\hline 4 & .265 & 5.306 & 97.124 & & & \\
\hline 5 & .144 & 2.876 & 100.000 & & & \\
\hline
\end{tabular}

Extraction Method: Principal Component Analysis.

Table 4.9 shows that only one factor had the greatest influence on the variations in laws. The factor accounted for $69.383 \%$ of all the variations. The factor had Eigen value of more than one and are therefore retained for further analysis. Since there is only retained factor the rotated component matrix was not generated.

\subsubsection{Factor Analysis for Stakeholders Interest}

To check on the sample adequacy of the data, KMO was used to check on the sample adequacy of the data. KMO value ranges between 0 and 1 with value more than 0.5 considered to be ideal, Ali et al (2016). For the Bartlett's test to be considered should have a $\mathrm{p}$ value of less than 0.05 for it to be considered significant, it must have a $\mathrm{p}$ value of less than 0.05.Table 4.6 shows that KMO was 0.568 and Bartlett's test of Sphericity had a p value of 0.000 which is less than 0.05 . Therefore the data can be subjected for further factor analysis tests.

Table4.10. KMO and Bartlett's Test

\begin{tabular}{|l|l|l|}
\hline \multicolumn{2}{|l|}{ Kaiser-Meyer-Olkin Measure of Sampling Adequacy. } & .568 \\
\hline Bartlett's Test of Sphericity & Approx. Chi-Square & 458.543 \\
\cline { 2 - 3 } & Df & 10 \\
\cline { 2 - 3 } & Sig. & .000 \\
\hline
\end{tabular}

Factor analysis helps in regrouping data into exhaustive and mutually exclusive clusters for ease of understanding and interpretation of relationships and patterns, Yong \& Pearce (2013). Principal component analysis was used to reduce components of stakeholders' interest. All the constructs of ownership were subjected to factor analysis and results given in Table 4.11 
Table4.11. Total Variance Explained

\begin{tabular}{|l|l|l|l|l|l|l|}
\hline \multirow{2}{*}{ Component } & \multicolumn{4}{|l|}{ Initial Eigenvalues } & \multicolumn{3}{l|}{ Rotation Sums of Squared Loadings } \\
\cline { 2 - 7 } & Total & \% of Variance & Cumulative \% & Total & \% of Variance & Cumulative \% \\
\hline 1 & 2.244 & 44.887 & 44.887 & 2.226 & 44.513 & 44.513 \\
\hline 2 & 1.754 & 35.080 & 79.967 & 1.773 & 35.455 & 79.967 \\
\hline 3 & .550 & 11.004 & 90.972 & & & \\
\hline 4 & .254 & 5.090 & 96.062 & & & \\
\hline 5 & .197 & 3.938 & 100.000 & & & \\
\hline
\end{tabular}

Table 4.11 shows that two factors had the greatest influence on the variations in stakeholder's interest. The two factors accounted for $79.967 \%$ of all the variations. The first factor accounted for $44.887 \%$ while the second one accounted for $35.080 \%$. The two factors had Eigen values of more than one and are therefore retained for further analysis.

\section{Rotated Component Matrix}

Table 4.12 presents the rotated component factor loadings for determinants of measures of stakeholder's interest. Two factors were retained. All the constructs with loading values of more than 0.4 were retained.

Table4.12. Rotated Component Matrix ${ }^{a}$

\begin{tabular}{|l|l|l|}
\hline & Component \\
\cline { 2 - 3 } & 1 & 2 \\
\hline Advertisers influence the radio stations programming format & .799 & \\
\hline The broadcaster influences radio stations programming content & & .941 \\
\hline The Regulator (CAK) influences stations programming type & .925 & \\
\hline The audience influence the radio station programming content & & .937 \\
\hline The regulator (CAK) influences the radio station programming content & .855 & \\
\hline $\begin{array}{l}\text { Extraction Method: Principal Component Analysis. } \\
\text { Rotation Method: Varimax with Kaiser Normalization. }\end{array}$ & \\
\hline a. Rotation converged in 3 iterations. & \\
\hline
\end{tabular}

\subsubsection{Factor Analysis for Programming Diversity}

To check on the sample adequacy of the data, KMO was used to check on the sample adequacy of the data. KMO value ranges between 0 and 1 with value more than 0.5 considered to be ideal, Ali et al (2016). For the Bartlett's test to be considered should have a p value of less than 0.05 for it to be considered significant, it must have a $p$ value of less than 0.05 . Table 4.19 shows that KMO was 0.583 and Bartlett's test of Sphericity had a p value of 0.000 which is less than 0.05 . Therefore the data can be subjected for further factor analysis tests.

Table4.19. KMO and Bartlett's Test

\begin{tabular}{|l|l|l|}
\hline \multicolumn{2}{|l|}{ Kaiser-Meyer-Olkin Measure of Sampling Adequacy. } & 0.583 \\
\hline \multirow{2}{*}{ Bartlett's Test of Sphericity } & Approx. Chi-Square & 121.33 \\
\cline { 2 - 3 } & Df & 10 \\
\cline { 2 - 3 } & Sig. & .000 \\
\hline
\end{tabular}

Factor analysis helps in regrouping data into exhaustive and mutually exclusive clusters for ease of understanding and interpretation of relationships and patterns, Yong \& Pearce (2013). Principal component analysis was used to reduce components of competition. All the constructs of ownership were subjected to factor analysis and results given in Table 4.20

Table4.20. Total Variance Explained

\begin{tabular}{|l|l|l|l|l|l|l|}
\hline \multirow{2}{*}{ Component } & \multicolumn{3}{|l|}{ Initial Eigenvalues } & \multicolumn{3}{l|}{ Rotation Sums of Squared Loadings } \\
\cline { 2 - 7 } & Total & \% of Variance & Cumulative \% & Total & \% of Variance & Cumulative \% \\
\hline 1 & 1.840 & 36.790 & 36.790 & 1.669 & 33.390 & 33.390 \\
\hline 2 & 1.044 & 20.881 & 57.672 & 1.214 & 24.282 & 57.672 \\
\hline 3 & .969 & 19.373 & 77.044 & & & \\
\hline 4 & .749 & 14.979 & 92.024 & & & \\
\hline 5 & .399 & 7.976 & 100.000 & & & \\
\hline
\end{tabular}

Table 4.20 shows that two factors had the greatest influence on the variations in programing diversity. The two factors accounted for $57.672 \%$ of all the variations. The first factor accounted for $33.390 \%$ 
while the second one accounted for $24.282 \%$. The two factors had Eigen values of more than one and are therefore retained for further analysis.

\section{Rotated Component Matrix}

Table 4.21 presents the rotated component factor loadings for determinants of measures of political interference. Two factors were retained. All the constructs with loading values of more than 0.4 were retained.

Table4.21. Rotated Component Matrix ${ }^{a}$

\begin{tabular}{|l|l|l|}
\hline \multicolumn{2}{|l|}{} & Component \\
\cline { 2 - 3 } & 1 & 2 \\
\hline DIVERSITY1 & & .406 \\
\hline DIVERSITY2 & .787 & \\
\hline DIVERSIT3 & .738 & .832 \\
\hline DIVERSITY5 & \multicolumn{2}{|l|}{} \\
\hline Extraction Method: Principal Component Analysis. \\
Rotation Method: Varimax with Kaiser Normalization. \\
\hline
\end{tabular}

\section{LINEAR REGRESSION ASSUMPTIONS}

Linear regression has been used to determine existence of relationships between independent variables and dependent variables. However, before fitting the linear regression model, it is always advisable to carry out a diagnosis analysis on the assumptions. These assumptions include, normality, multicollinearity, autocorrelation, homoscedasticity and linearity. In this research normality, autocorrelation and multicollinearity were tested.

\subsection{Normality Test}

The results of Kolmogorov Smirnov test is given in Table 4.21.

Table4.21. One-Sample Kolmogorov-Smirnov Test

\begin{tabular}{|c|c|c|c|c|c|c|}
\hline & ownership & laws & stakeholder & competition & political \\
\hline \multicolumn{2}{|l|}{$\mathrm{N}$} & 210 & 210 & 210 & 210 & 210 \\
\hline \multirow{2}{*}{ Normal Parameters ${ }^{\mathrm{a}, \mathrm{b}}$} & Mean & 3.78 & 2.73 & 3.88 & 4.11 & 3.77 \\
\hline & Std. Deviation & .904 & .670 & .914 & .584 & .477 \\
\hline \multirow{3}{*}{ Most Extreme Differences } & Absolute & .037 & .043 & .030 & .034 & .045 \\
\hline & Positive & .029 & .043 & .030 & .034 & .045 \\
\hline & Negative & -.037 & -.025 & -.025 & -.027 & -.038 \\
\hline \multicolumn{2}{|l|}{ Kolmogorov-Smirnov Z } & .532 & .621 & .436 & .498 & .650 \\
\hline \multicolumn{2}{|l|}{ Asymp. Sig. (2-tailed) } & .940 & .835 & .991 & .965 & .792 \\
\hline
\end{tabular}

Table 4.21 shows that the null hypothesis is not rejected since the $\mathrm{p}$ value is less than 0.05 . Therefore the data can be assumed to be normal.

\subsection{Auto Correlation Results}

The second assumption of linear regression is that there should be no serial correlation among the residuals. When there exists serial correlation in the data, results tend to be inefficient results. In this research Durbin and Watson's statistics was used to detect presence of auto correlation (Yupitun, 2008).

Table4.23. Durbin-Watson (Autocorrelation) Results

\begin{tabular}{|l|l|l|l|l|l|}
\hline Model & R & R Square & Adjusted R Square & Std. Error of the Estimate & Durbin-Watson \\
\hline 1 & .722 & .522 & .512 & .5615 & 1.954 \\
\hline
\end{tabular}

Durbin-Watson statistic takes values between 0 and 4 with an ideal value of 2 indicating that the error terms are not correlated. Values between 1.75 and 2.25 may be considered acceptable. Results from Table 4.23 shows that the Durbin Watson value was 1.954 which indicates that there was no serial correlation among the error terms. 


\subsection{Multicollinearity}

In multiple linear regression model, it is always assumed that any pair of the independent variables does not have exact correlation between themselves or near perfect relationship. There are several tests available to test multicollinearity. In this research, variance inflation factor was used and the results given by Table 4.24

Table4.24. VIF factor

\begin{tabular}{|l|l|l|}
\hline \multirow{2}{*}{ Model } & Collinearity Statistics \\
\cline { 2 - 3 } & Tolerance & VIF \\
\hline OWNERSHIPS & .965 & 1.036 \\
\hline LAWS & .360 & 2.776 \\
\hline STAKEHOLDERS & .300 & 3.328 \\
\hline COMPETITION & .599 & 1.668 \\
\hline
\end{tabular}

A VIF value of close to one indicates lack of multicollinearity. Values of more than 4 implies that there is presence of multicollinearity. Values between 1 and 4 are considered to be good signs of lack of multicollinearity. Table 4.24 shows that there were no issues of multicollinearity detected in the data since all the values are between 1 and 4.

\subsection{Correlation Results}

To determine the nature of the relationship ad to measure the strength of the relationship between the independent and dependent variables, Pearson Correlation coefficient was used. Pearson correlation coefficients take values between -1 and +1 . Values less than 0 implies existence of a negative relationship while values above 0 implies a positive relationship. Values close 1 (absolute) shows presence of very strong relationship and values close to zero points to very weak relationship. Table 4.25 presents the results of Correlation analysis

Table4.25. Correlation Analysis

\begin{tabular}{|c|c|c|c|c|c|c|}
\hline & & 1 & 2 & 3 & 4 & 5 \\
\hline \multirow{3}{*}{ OWNERSHIPS (1) } & Pearson Correlation & 1 & & & & \\
\hline & Sig. (2-tailed) & & & & & \\
\hline & $\mathrm{N}$ & 210 & & & & \\
\hline \multirow{3}{*}{ LAWS (2) } & Pearson Correlation & -.026 & 1 & & & \\
\hline & Sig. (2-tailed) & .703 & & & & \\
\hline & $\mathrm{N}$ & 210 & 210 & & & \\
\hline \multirow{3}{*}{ STAKEHOLDERS (3) } & Pearson Correlation & .105 & $.705^{* * *}$ & 1 & & \\
\hline & Sig. (2-tailed) & .130 & .000 & & & \\
\hline & $\mathrm{N}$ & 210 & 210 & 210 & & \\
\hline \multirow{3}{*}{ COMPETITION (4) } & Pearson Correlation & $.159^{*}$ & -.053 & $.409^{* * * *}$ & 1 & \\
\hline & Sig. (2-tailed) & .022 & .446 & .000 & & \\
\hline & $\mathrm{N}$ & 210 & 210 & 210 & 210 & \\
\hline \multirow{3}{*}{ DIVERSITY(5) } & Pearson Correlation & $.588^{* *}$ & $.385^{* *}$ & $.332^{* *}$ & $.157^{*}$ & 1 \\
\hline & Sig. (2-tailed) & .000 & .000 & .000 & .023 & \\
\hline & $\mathrm{N}$ & 210 & 210 & 210 & 210 & 210 \\
\hline
\end{tabular}

From the results given in Table 4.25, it can be shown that there exists a strong positive significant relationship between ownership and program diversity; there exists average positive significant relationships between laws and programming diversity and stakeholders' interest and programming diversity; there exists a positive significant relationship (weak) between competition and programming diversity. There relationships were considered significant since their correlation coefficients had a $\mathrm{p}$ value of less than 0.05 .

\section{REGRESSION RESULTS}

The regression results are given in the sub sections that follow.

\subsection{The Model Summary}

The model summary presents the combined influence of all the independent variables on the dependent variables. It shows the extent of the variation in the dependent variable explained by the model. Table 4.26 presents the results of the model salary 
Table4.26. Model Summary

\begin{tabular}{|c|c|c|c|c|}
\hline Model & $\mathrm{R}$ & R Square & Adjusted R Square & Std. Error of the Estimate \\
\hline 1 & $.722^{\mathrm{a}}$ & .522 & .512 & .58424 \\
\hline 2 & $.824^{\mathrm{b}}$ & .679 & .666 & .48335 \\
\hline \multicolumn{5}{|c|}{ a. Predictors: (Constant), COMPETITION, LAWS, OWNERSHIPS, STAKEHOLDERS } \\
\hline \multicolumn{5}{|c|}{$\begin{array}{l}\text { b. Predictors: (Constant), COMPETITION, LAWS, OWNERSHIPS, STAKEHOLDERS, moderator4, } \\
\text { moderator 1, moderator2, moderator3 }\end{array}$} \\
\hline
\end{tabular}

Table 4.26 model 1 shows that ownership, laws, stakeholders' interest and competition explains $52.2 \%$ of all the variations in programming diversity. Other factors not considered in the model explain $47.8 \%$ of all the variations in programming diversity. This implies that there is a good explanatory power in the model. When the moderating variable (political factors) was introduced, the explanatory power increased to $67.9 \%$. This implies that the moderating variable has induced about $15.7 \%$ additional influence on the variations in programming diversity.

\subsection{The ANOVA Results}

The ANOVA table generally presents the results on the test of the null hypothesis that none of the independent variable is significant against the alternative that at least one of them is significant. The ANOVA results are given in Table 4.27

Table4.27. ANOVA ${ }^{a}$

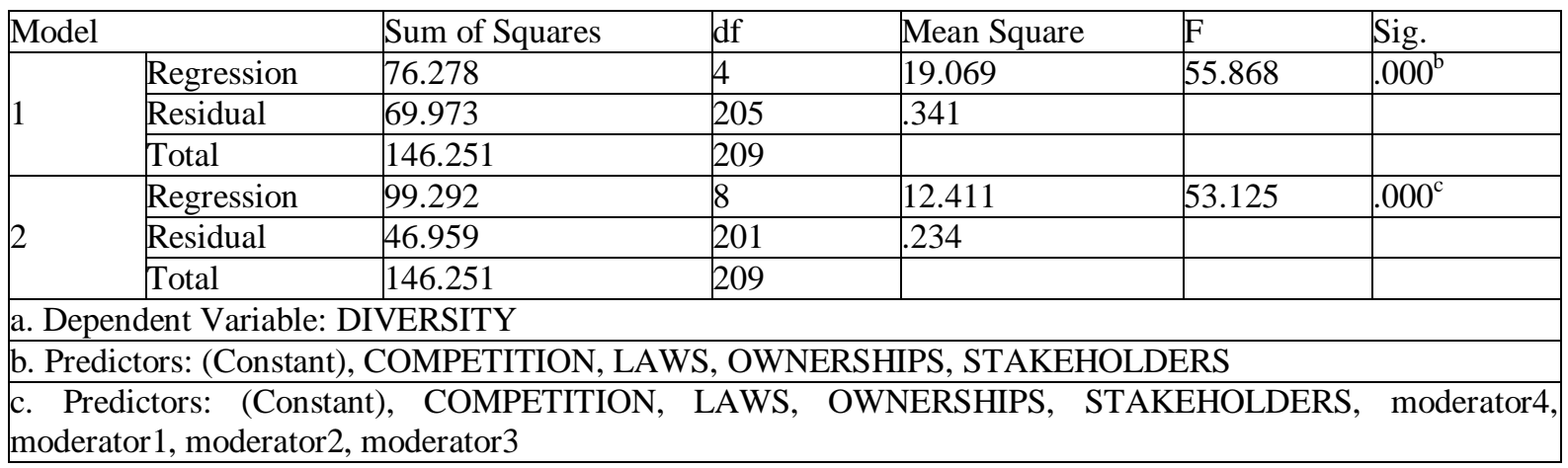

Results given in Table 4.27 shows that in model 1 (in the absence of moderating variable) at least one variable was significant. This is supported by a large $F$ test value (55.868) and a very small $p$ value (0.000). The null hypothesis is always rejected when the $\mathrm{p}$ value is less than 0.05 . When the moderating variable was introduced, the $\mathrm{F}$ test statistics value decreases to 53.125 while the $\mathrm{p}$ value remains less than 0.05 . This implies that the null hypothesis is still rejected; political factors have a moderating effect on at least one of the independent variables.

\subsection{Regression Results}

To establish the influence of Influence of Radio Ownership Concentration on Programming diversity in Kenya (ownership, laws, stakeholder's influence and competition) using political factors as moderating variable, the following hypotheses were stated:

\section{- Hypothesis One}

$\mathrm{H}_{01}$ : Ownership has no statistically significant influence on programming diversity

$\mathrm{H}_{0 \mathrm{~A}}: \quad$ Ownership has statistically significant influence on programming diversity

\section{- Hypothesis two}

$\mathrm{H}_{01}$ : Laws have no statistically significant influence on programming diversity

$\mathrm{H}_{0 \mathrm{~A}}$ : Laws have statistically significant influence on programming diversity

- Hypothesis Three

$\mathrm{H}_{01}$ : Stakeholders' interest have no statistically significant influence on programming diversity

$\mathrm{H}_{0 \mathrm{~A}}$ : Stakeholders' interest have statistically significant influence on programming diversity.

\section{- Hypothesis Four}

$\mathrm{H}_{01}$ : Competition has no statistically significant influence on programming diversity

$\mathrm{H}_{0 \mathrm{~A}} \quad$ Competition has statistically significant influence on programming diversity 
To test the hypotheses 1 to 4 regression analysis was used. Table 4.28 gives the regression coefficients. Model one shows the results without the moderating variable (Political).

\section{Coefficients $^{\mathrm{a}}$}

\begin{tabular}{|c|c|c|c|c|c|c|}
\hline \multirow[t]{2}{*}{ Model } & & \multicolumn{2}{|c|}{ Unstandardized Coefficients } & \multirow{2}{*}{\begin{tabular}{|l} 
Standardized Coefficients \\
Beta
\end{tabular}} & \multirow[t]{2}{*}{$t$} & \multirow[t]{2}{*}{ Sig. } \\
\hline & & $\mathrm{B}$ & Std. Error & & & \\
\hline \multirow{5}{*}{1} & (Constant) & .246 & .340 & & .724 & .470 \\
\hline & OWNERSHIPS & .510 & .042 & .595 & 12.090 & .000 \\
\hline & LAWS & .377 & .058 & .526 & 6.529 & .000 \\
\hline & STAKEHOLDERS & -.158 & .084 & -.166 & -1.881 & .061 \\
\hline & COMPETITION & .234 & .093 & .158 & 2.528 & .012 \\
\hline \multirow{9}{*}{2} & (Constant) & .021 & .313 & & .067 & .947 \\
\hline & OWNERSHIPS & 3.027 & 327 & 3.530 & 9.245 & .000 \\
\hline & LAWS & -.589 & .386 & -.821 & -1.525 & .129 \\
\hline & STAKEHOLDERS & .067 & .727 & .070 & .091 & .927 \\
\hline & COMPETITION & -1.944 & .616 & -1.310 & -3.157 & .002 \\
\hline & moderator 1 & -.675 & .090 & -3.058 & -7.492 & .000 \\
\hline & moderator2 & .220 & .104 & 1.344 & 2.109 & .036 \\
\hline & moderator 3 & -.045 & .189 & -.235 & -.240 & .810 \\
\hline & moderator4 & .606 & .159 & 1.991 & 3.816 & .000 \\
\hline
\end{tabular}

Results from Table 4.28 (Model 1) shows that laws, competition and ownership have positive significant influence on programming diversity. Stakeholder's interest have negative influence but not significant at 5\% level of significance. This is because the $p$ values of their test statistics are less than 0.05 . Model 1 can be summarized using equation 4.1 as

$Y_{i}=0.51 X_{1}+0.377 X_{2}+0.234 X_{3}$

Where $X_{1}, X_{2}$ and $X_{3}$ are ownership, laws and competition respectively.

Equation 4.1 shows that for every one unit change in ownership, programming diversity increases by $51 \%$, for every one unit change in laws, programming diversity increases by $37.7 \%$ and for every one unit change in competition, programming diversity increases by $23.4 \%$.

Therefore, the null hypotheses 1, 2 and 4 are rejected while 2 is not rejected. It can be concluded that ownership, laws and competition have significant influence on programming diversity.

\section{- Hypothesis Five}

$\mathrm{H}_{01}$ : There is no statistically significant moderating influence of political factors on the relationship between radio ownership concentration and programming diversity in Kenya

$\mathrm{H}_{0 \mathrm{~A}}$ : There is no statistically significant moderating influence of political factors on the relationship between radio ownership concentration and programming diversity in Kenya Moderated (saturated) regression analysis was also conducted to empirically determine if political factors have had any significant influence on the radio ownership concentration and programming diversity in Kenya.

Results from Table 4.28 shows that interaction effect of ownership and political factors have negative significant influence on the programming diversity in Kenya; interaction effect of laws and political factors have positive significant influence on the programming diversity in Kenya; interaction effect of competition and political factors have positive significant influence on the programming diversity in Kenya. However, interaction effect of stakeholder's interest and political factors have positive significant influence on the programming diversity in Kenya.

Table4.28. Summary of Research Hypotheses

\begin{tabular}{|l|l|}
\hline Null Hypothesis & Comments \\
\hline $\begin{array}{l}\text { 1. There is no statistically significant influence of ownership on the programming diversity } \\
\text { in Kenya. }\end{array}$ & Rejected \\
\hline $\begin{array}{l}\text { 2. There is no statistically significant influence of laws on the programming diversity in } \\
\text { Kenya. }\end{array}$ & Rejected \\
\hline
\end{tabular}




\begin{tabular}{l}
$\begin{array}{l}\text { 3. There is no statistically significant influence of stakeholder's interest on the } \\
\text { programming diversity in Kenya. }\end{array}$ \\
$\begin{array}{l}\text { 4. There is no statistically significant influence of competition on the programming } \\
\text { diversity in Kenya. }\end{array}$ \\
\hline $\begin{array}{l}\text { 5. There is no statistically significant moderating effects of political factors on the } \\
\text { relationship between radio ownership concentration and programming diversity in Kenya. }\end{array}$ \\
\hline
\end{tabular}

\section{CONCLUSION}

The Radio through it's programming plays an important role in educating and entertaining the public. Given this vital role the question of ownership and the availability of diverse programming in the media is an issue of concern. A healthy media is often claimed to be the life-blood of democracy. This is because news provides, or should provide, the vital resources for processes of information gathering, deliberation and analysis that enables citizens to participate in political life and democracy to function better. For this to happen there is need for programmes to represent a wide range of issues from a variety of perspectives and with a diversity of voices.

\section{REFERENCES}

[1] Altschull, J.H. (1984). Agents of Power: The of the News Media in Human Affairs.

[2] New York: Longman.

[3] Baker Edwin C (2007) Media Concentration and Democracy: Why Ownership Matters. Cambridge: Cambridge University Press

[4] Chambers, T. \& Howards, H. (2006). "The Economics of Media Consolidation". In Albarran, B.A., ChanOlmsted, M.S. \& Wirth, O.M. (eds), Handbook of Media Management and Economics. Mahwah, NJ: Lawrence Erlbaum Associates:

[5] Doyle, G (2006): Media Ownership. Sage Publications Limited

[6] Gomery, D. (2006). Media Economics: Terms of Analysis. In G. Doyle (Ed.), the Economics of Mass Media, the International Library of Critical Writing in Economics. Cheltenham: Edward Elgar Publishing Limited

[7] Golding, P. \& Murdock, G. (2001). Political Economy of the Media. London: Arnold.

[8] Kothari, C., \& Garg, G. (2014). Research Methodology. New a ge International (P) Ltd. Publishers. New Delhi

[9] Mosco, V. (1996). The Political Economy of Communication: Rethinking and Renewal. London: Sage

[10] McChesney, W. R, (2008). The Political Economy of Media: Enduring Issues, Emerging Dilemmas. New york: Monthly Review Press

[11] McQuail, D. (2005). Mass Communication Theory. (5th ed.) London: Sage Publication

[12] Nyabuga G. (2009) "Media owenership, editorial independence and accountability". In: Media and development Forum. Freetom, Sierra Leone: 2012

[13] Napoli, P.M. (2006). Issues in media Management and Public Interest'. In Albarran, B.A., Mahwah, NJ: Lawrence Erlbaum Associates

[14] Strinati, D., (1995). An Introduction to Theories of Popular Culture. London: Routledge

[15] Williams, B. (2003, may 29). Behind closed: Top broadcasters met 71 times with FCC officials. The Centre for Public Intergrity

[16] Yong, Pearce (2013). A beginner's guide to factor analysis: Focusing on exploratory factor analysis. New York

Citation: Allan S. Wekesa, et al. "Examining the Influence of Media Ownership Concentration on Radio Programing Diversity in Kenya". International Journal of Media, Journalism and Mass Communications (IJMJMC), vol 6, no. 1, 2020, pp. 28-38 doi: http://dx.doi.org/10.20431/2454-9479.0601004

Copyright: (1) 2020 Authors. This is an open-access article distributed under the terms of the Creative Commons Attribution License, which permits unrestricted use, distribution, and reproduction in any medium, provided the original author and source are credited. 